\title{
The Effect of Anxiety and Depression on Bruxism Among Healthcare Workers During the Covid-19 Pandemic
}

\author{
Covid-19 Pandemisinde Görevli Sağlık Çalışanlarında Anksiyete ve Depresyonun \\ Bruksizm Üzerine Olan Etkisi \\ Başak Çiğdem KARACAY ${ }^{1}$ (iD) Cansın MEDIN CEYLAN ${ }^{2}$ iD Merve Damla KORKMAZ ${ }^{3}$ \\ Tuğba $S$ AHBAZ
}

$\underline{\text { OZZ }}$

Amaç: Koronavirüs hastalığı 2019 (COVID-19), pandemik düzeyde olarak ortaya çıkan bulaşıcı bir hastalıktır. COVID-19 hastalarını tedavi eden sağlık uzmanları, ülkenin sağlık ihtiyaçlarını karşılamak için uzun mesai sürelerinde ve yüksek enfeksiyon riskine maruz kalarak çalışmaktadır. Bu durum, uzun süreli strese neden olabilir. Bu çalışmada pandemide görev alan sağlık çalışanlarında bruksizm, anksiyete ve depresyon sıklığını ve birbirleriyle ilişkilerini değerlendirmeyi amaçladık.

Araçlar ve Yöntem: Çalışmamız, çevrimiçi kanallar aracılı̆̆ıyla yürütülen kesitsel bir anket çalışmasıdır. Türkiye'de COVID-19 hastalarına bakmakta olan sağlık çalışanları online kanalllar yolu ile, Hastane Anksiyete ve Depresyon Ölçeği, demografik ek bilgiler ve bruksizm sıklı̆̆ını değerlendiren kendi kendine uygulanan bir ankete katılmaya davet edildi.

Bulgular: Çalışmamıza dört yüz yirmi bir sağlık çalışanı dahil edildi. Ortalama yaș $32.8 \pm 7.06$ idi. Pandemi süreci öncesinde șikayeti olmayan 263 kişiden 57'si bu dönemde ilk kez bruksizm geliştiğini ve 32 kişi ise gece uykuda bruksizm şikayetinin başladığını belirttiler. Anksiyete ve depresyon değerlendirmelerinde kadınların erkeklere göre anlamlı olarak daha yüksek anksiyete ve depresyon puanları vardı $(\mathrm{p}<0.001)$. Meslek itibarıyla en yüksek anksiyete (\% 72.4) ve depresyon (\% 63.8) oranı yardımcı sağlık personelindeydi.

Sonuç: Pandemide çalışmak, sağlık çalışanlarının fiziksel sağlığını olduğu kadar mental sağlığını da etkiler. Türk sağlık çalışanlarında bruksizm, pandemi sırasında anksiyete ve depresyondaki artışa paralel olarak ortaya çıkmaktadır.

Anahtar Kelimeler: bruksizm; COVID-19; sağlık çalışanları

\section{ABSTRACT}

Purpose: Coronavirus disease 2019 (COVID-19) is an emerging infectious disease of pandemic proportions. Healthcare professionals who treat COVID-19 patients are exposed to a high risk of infection and long work shifts to meet the country's health needs. This situation can lead to prolonged exposure to stress. We aimed to evaluate the frequency of bruxism, anxiety and depression and their relationships with each other.

Materials and Methods: Our study is a cross-sectional survey study conducted through online channels. Health care workers in Turkey who were caring for patients with COVID-19 were invited to participate with a self-administered questionnaire to evaluate the frequency of bruxism, Hospital Anxiety and Depression Scale that was analyzed as global scoring, anxiety and depression subscale in addition to information on demographic characteristics

Results: Four hundred and twenty-one healthcare professionals were included in our study. The average age was $32.8 \pm 7.06$. Of the 263 people who did not have complaints before the pandemic process, 57 stated that they had suffered bruxism, and 32 stated that they had a sleep bruxism complaint at night for the first time. In anxiety and depression evaluations, women had significantly higher anxiety and depression scores compared to men $(\mathrm{p}<0.001)$. By profession, the highest anxiety $(72.4 \%)$ and depression $(63.8 \%)$ rates were in the auxiliary healthcare personnel.

Conclusion: Working in pandemic affects health workers' physical health as well as mentally like bruxism. It appears in parallel with the increase of anxiety and depression in Turkish health workers during pandemic.

Keywords: bruxism; COVID-19; healthcare professionals

Received: 28.08.2020, Accepted: 28.02.2021

${ }^{1}$ Yozgat Yerköy State Hospital, Yozgat, Turkey

${ }^{2}$ University of Health Sciences, Istanbul Physical Therapy Rehabilitation Training and Research Hospital, Department of Physical Medicine and Rehabilitation, Istanbul, Turkey.

${ }^{3}$ University of Health Sciences, Kanuni Sultan Suleyman Training and Research Hospital, Department of Physical Medicine and Rehabilitation, Istanbul, Turkey.

Corresponding Author: Tuğba Şahbaz, University of Health Sciences, Kanuni Sultan Suleyman Training and Research Hospital, Department of Physical Medicine and Rehabilitation, Istanbul, Turkey. e-mail: piskint@gmail.com

How to cite: Karacay BÇ, Ceylan CM, Korkmaz MD, Şahbaz T. The effect of anxiety and depression on bruxism among healthcare workers during the covid-19 pandemic. Ahi Evran Med J. 2021;5(2):78-84. DOI: 10.46332/aemj.787182 


\section{INTRODUCTION}

The COVID-19 epidemic, caused by a coronavirus, is an epidemic that typically affects the respiratory system, and has been declared as a pandemic. ${ }^{1}$ COVID-19 cases were first identified in the city of Wuhan, in China's Hubei province, but the COVID-19 outbreak has become a public event as an increasing epidemic. ${ }^{2-4}$ According to the official website of the World Health Organization, as of June 15,2020 , more than 2 million people globally have been confirmed to have COVID-19 (confirmed cases: 7.761.609 death:430.241) ${ }^{5}$. As of June 15, 2020, there have been more than 150.000 new diagnoses in Turkey. ${ }^{6}$ Many successes have been achieved in COVID-19, including virus knowledge, clinical features, and diagnosis, but no effective treatment is available yet. ${ }^{2,7-9}$

The first COVID-19 case in Turkey was detected on March 11, 2020. ${ }^{10}$ With the first case seen, we entered into a phase that could be overcome only by cooperating with all healthcare workers to cope with this infection. ${ }^{10,11}$ Healthcare professionals who treat COVID-19 patients are exposed to a high risk of infection and long work shifts to meet the country's health needs. This situation can lead to prolonged exposure to stress, which can exceed individual coping skills. ${ }^{12}$ Causes of stress include the idea that the person and his family may be infected, have limited access to official psychological support, limited information about the epidemic, a lack of learning the correct use of protective equipment, and less medical information ${ }^{13}$. Some studies have observed that mental health is affected by the increase in stress levels during the struggle of health workers with infection. ${ }^{12-14}$

Bruxism is the abnormal activities of the chewing muscle observed during sleep or wakefulness ${ }^{15}$. Bruxism is a common clinical condition that often causes pain or damaged tooth and jaw joint structure ${ }^{16}$. It may cause dental abrasions, dental fractures, mobility, pain and sound in the temporomandibular joint (TMJ) region and chewing muscles, loss of periodontal support, and rarely headaches. ${ }^{17,} 18$

Although studies on the etiology of bruxism increase day by day, it is a more accepted view that bruxism develops as a response to anxiety and stress. ${ }^{18}$
In addition, male gender, genetic predisposition, anger, psychological reactions, responsibilities, headache, emotional and mental problems are among the causes of bruxism. ${ }^{17,18}$ The purpose of this study was to evaluate the effect of anxiety caused by the pandemic on bruxism among healthcare workers and also the frequency of bruxism, anxiety, and depression and their relationships with each other.

\section{MATERIALS and METHODS}

\section{Study Population}

The current study is a cross-sectional survey study conducted through online channels. The study was conducted 8 weeks after the COVID-19 outbreak in Turkey. This period coincides with the period after the peak of the outbreak in Turkey. This survey also includes sociodemographic information. Healthcare workers involved in the fight against the pandemic in Turkey (doctors, nurses, medical secretaries, auxiliary healthcare personnel) who agreed to participate in the survey study were included. Participants with a history of previous jaw surgery, a history of jaw trauma and a systemic disease affecting the jaw were not included in the study. Those who gave up using the online platform were not included in the study.

\section{Measurements}

Demographic data, occupation, duration of working during the pandemic, monthly working time, previously diagnosed jaw disease, history of bruxism and presence of newly started bruxism, symptom increase, presence of night teeth grinding, anxiety and depression were questioned. The voluntary consent form and hospital anxiety and depression scale were filled in by the healthcare professionals who took an active role in the COVID-19 pandemic.

The Hospital Anxiety and Depression Scale (HADS) was developed by Zigmond and Snaith (1983). ${ }^{19}$ The scale consists of 14 items. Seven of these items measure anxiety and seven of them measure the symptoms of depression. Each item of the scale is given a score between 0-3. According to the scoring system, 0-1 mean healthy, 2 means borderline patient and 2-3 mean severe patient. Scores for seven 
questions evaluating anxiety and depression are collected separately, and 0-7 points mean normal, 8-10 points mean borderline abnormal, and 11 and above are evaluated as abnormal. ${ }^{20}$ The purpose of the scale is not to diagnose, but to measure the psychological status of patients and to take necessary measures. ${ }^{19}$

Based on this information, in order to determine the effect of the pandemic on bruxism, a total of 175 people who started a new bruxism complaint, had a bruxism complaint in the past, or had an increase in these complaints were considered as the bruxism group.

\section{Ethical Approval}

All procedures performed in this study involving human participants were in accordance with the ethical standards of the institutional ethics committee (Yozgat Bozok University, 20/05/2020, 60174989-2020-103) and with the 1964 Helsinki declaration and its later amendments or comparable ethical standards. Written informed consent was obtained from all participants included in the study.

\section{Statistical Analysis}

According to the legal authorities, there were 1.061.635 healthcare professionals working in the pandemic. Power analysis was performed based on the $\mathrm{n}=\mathrm{Nz}^{2} \mathrm{P}(1-\mathrm{P}) /\left(\mathrm{d}^{2}(\mathrm{~N}-\right.$ $\left.1)+z^{2} P(1-P)\right)$ formula, and 384 subjects were planned to be included in the study when $\mathrm{d}, \mathrm{P}$ and $\mathrm{z}$ values in the formula were considered to be as $0.05,0.5$ and 1.96 , respectively. ${ }^{21}$

In the statistical analysis of all data, IBM SPSS Version 22.0 (Statistical Package for the Social Sciences, Statistics for Windows. Armonk, NY: IBM Corp.) was used. Mean and standard deviation values in parametric tests in descriptive statistics of the data were used. In nonparametric tests, the median values, the minimum and maximum values were used. The distribution of variables was checked with the Kolmogorov-Smirnov test. To compare two groups, an independent sample t-test was performed for quantitative variables, and $\chi 2$ test was performed for the categorical data. Independent variables were screened by univariate analysis at first and analyzed by Logistic regression. The results were evaluated in the $95 \%$ confidence interval and $\mathrm{p}<0.05$ was defined as statistical significance.

\section{RESULTS}

Four hundred and twenty-one healthcare professionals who voluntarily accepted to fill in our survey and answered the questions completely were included in our study. Of the healthcare professionals, 313 were women and 107 were men. The mean age was $32.8 \pm 7.06$. Considering the distribution of professions, $30.0 \%(\mathrm{n}=124)$ of them were physicians, $33.4 \%(\mathrm{n}=138)$ were nurses, $14.8 \%$ $(\mathrm{n}=61)$ were medical secretaries, $12.3 \%(\mathrm{n}=51)$ were other healthcare workers and $9.7 \%(n=40)$ were pharmacists. The individuals included in the study were working with pandemic patients $32.52 \pm 19.95$ hours per week (Table 1).

Table 1. Demographic and clinical parameters of the patients.

\begin{tabular}{lc}
\hline Variables & Data $(\mathbf{N}=\mathbf{4 2 1})$ \\
\hline WithBruxism/ & $246 / 175$ \\
Without Bruxism & \\
Age (yr) & $32.82 \pm 7.06$ \\
Gender M/F & $108 / 313$ \\
Week & $3.74 \pm 1.40$ \\
Anxiety & \\
Normal & 91 \\
B.abnormal & 87 \\
Abnormal & 243 \\
Depression & \\
Normal & 94 \\
B.abnormal & 112 \\
Abnormal & 225 \\
\hline
\end{tabular}

One hundred fifty-eight people who participated in the study stated that they had complaints of bruxism at some point in their lives, and 83 people complained of sleep bruxism before the pandemic. One hundred and eighteen of these individuals reported an increase in bruxism complaints, and 38 reported an increase in sleep bruxism after the pandemic. Out of 263 people who did not have complaints before the pandemic process, 57 stated that they had suffered bruxism, and 32 stated that they had a sleep bruxism complaint at night for the first time in their lives (Table 2). The group with the highest level of bruxism was auxiliary healthcare personnel (56.9\%) and the least was secretaries $(29.5 \%)$. 
Table 2. Distribution of pre and post-pandemic cases of bruxism and sleep bruxism according to anxiety and depression levels.

\begin{tabular}{|c|c|c|c|c|c|}
\hline & $\begin{array}{l}\text { Complaints of } \\
\text { Bruxism Before } \\
\text { Pandemic }\end{array}$ & $\begin{array}{c}\text { Increased Compla- } \\
\text { ints } \\
\text { Of Bruxism After } \\
\text { Pandemic } \\
\end{array}$ & $\begin{array}{c}\text { New-Onset } \\
\text { Bruxism }\end{array}$ & $\begin{array}{l}\text { Increased Compla- } \\
\text { ints } \\
\text { on Working Days }\end{array}$ & $\begin{array}{c}\text { New-Onset } \\
\text { Sleep Bruxism }\end{array}$ \\
\hline \multicolumn{6}{|l|}{ Anxiety } \\
\hline Normal & $25(15.8 \%)$ & $11(9.3 \%)$ & $2(3.5 \%)$ & $15(9.5 \%)$ & $1(3.1 \%)$ \\
\hline B.abnormal & $29(18.4 \%)$ & $26(22.0 \%)$ & $9(15.8 \%)$ & $31(19.6 \%)$ & $7(21.9 \%)$ \\
\hline Abnormal & $104(65.8 \%)$ & $81(68.6 \%)$ & $46(80.7 \%)$ & $112(70.9 \%)$ & $24(75.0 \%)$ \\
\hline \multicolumn{6}{|l|}{ Depression } \\
\hline Normal & $28(17.7 \%)$ & $10(8.5 \%)$ & $3(5.3 \%)$ & $14(8.9 \%)$ & $2(6.3 \%)$ \\
\hline B.abnormal & $54(34.2 \%)$ & $37(31.4 \%)$ & $10(17.5 \%)$ & $38(24.1 \%)$ & $5(15.6 \%)$ \\
\hline Abnormal & $76(48.1 \%)$ & $71(60.2 \%)$ & $44(77.2 \%)$ & $106(67.1 \%)$ & $25(78.1 \%)$ \\
\hline
\end{tabular}

B.abnormal: Borderline abnormal

Female to male ratio of the patients with new-onset bruxism or aggravation of preexisting bruxism complaints after pandemics was 146/29. In the Hospital Anxiety and Depression Scale (HADS), anxiety assessment was abnormal in 243 people, 87 people were borderline abnormal, and 91 were normal. According to the depression scale, 215 people were abnormal, 112 were borderline abnormal and 94 were normal. When the association of bruxism with depression and anxiety was evaluated, it was observed that anxiety and bruxism were present together in $72.6 \%$, and depression and bruxism in $65.7 \%$ of the participants (Figure 1-2).

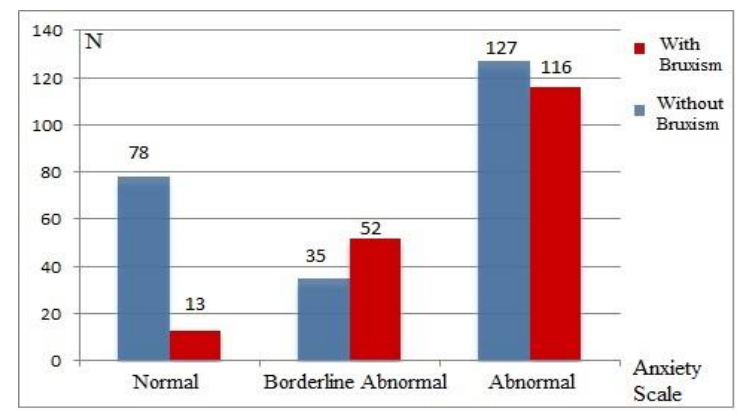

Figure 1. Relationship between bruxism and anxiety level

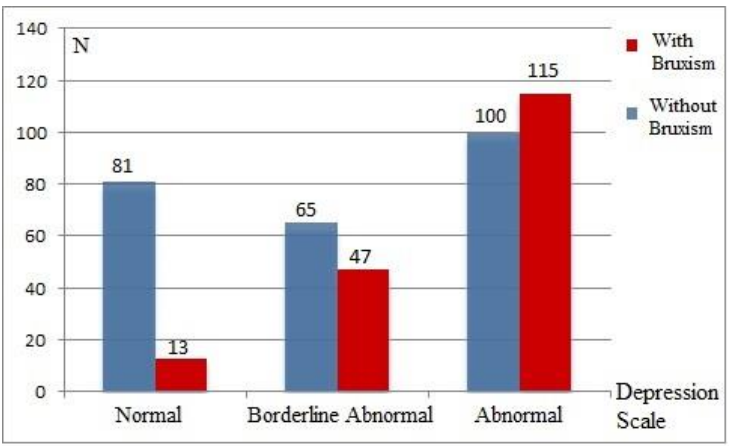

Figure 2. Relationship between bruxism and depression level
In anxiety and depression evaluations, women had significantly higher levels of anxiety and depressionscores compared to men $(\mathrm{p}<0.001)$. By profession, the highest anxiety rate was in the auxiliary healthcare personnel $(72.4 \%)$, followed by nurses $(65.2 \%)$, pharmacists $(62.5 \%)$, secretaries (57.4\%), and doctors with the lowest rate (41.1\%). Regarding depression rates, the highest rate was in auxiliary healthcare personnel with $63.8 \%$, followed by secretaries $(59.0 \%)$, nurses $(55.1 \%)$, pharmacists $(52.5 \%)$ and doctors (36.3\%).

Univariate and logistic regression analyses were performed to determine the factors affecting bruxism in healthcare professionals with new-onset bruxism or aggravation of preexisting complaints after pandemics. On univariate analysis, sex, occupation, anxiety and depression were found to have significant effects on bruxism $(\mathrm{p}<0.05)$. On binary logistic regression analysis, while bruxism was found to be significantly less in secretaries compared to other occupational groups, it was found to be significantly higher in both abnormal and borderline abnormal individuals according to anxiety and depression values $(\mathrm{p}<0,05)($ Table3). 
Table 3. Univariate and logistic regression analysis of factors affecting bruxism.

\begin{tabular}{|c|c|c|c|c|c|c|c|}
\hline & \multirow[b]{2}{*}{ With Bruxism } & \multirow[b]{2}{*}{ Without Bruxism } & \multicolumn{2}{|c|}{ Univariate } & \multicolumn{3}{|c|}{ Binary Logistic Regression Analyses } \\
\hline & & & $\chi^{2}$ & p-value & $\begin{array}{l}\text { Odds Ra- } \\
\text { tio }\end{array}$ & $\begin{array}{c}\text { \%95 CI } \\
\text { (Lower-Upper) }\end{array}$ & p-value \\
\hline Age (Min-Max) & $32.6 \pm 6.6(22-53)$ & $33.0 \pm 7.6(21-54)$ & & 0.899 & & & \\
\hline $\operatorname{Sex}(\mathbf{F} / \mathbf{M})$ & $167 / 79$ & $146 / 29$ & 12.951 & $<0.001$ & 0.609 & $0.340-1.089$ & 0.094 \\
\hline Week $(\%)$ & & & & & & & 0.104 \\
\hline $0-2$ & $40(16.3 \%)$ & $21(12.0 \%)$ & & & & & (ref) \\
\hline $2-4$ & $171(69.5 \%)$ & $114(65.1 \%)$ & 6.407 & 0.093 & 1.007 & $0.526-1.928$ & 0.984 \\
\hline 4-6 & $31(12.6 \%)$ & $33(18.9 \%)$ & & & 1.830 & $0.818-4.093$ & 0.141 \\
\hline$>6$ & $4(1.6 \%)$ & $7(4.0 \%)$ & & & 3.120 & $0.748-13.012$ & 0.118 \\
\hline Occupation (\%) & & & & & & & 0.028 \\
\hline Doctor & $\begin{array}{l}82(33.3 \%) \\
70(28.5 \%)\end{array}$ & $42(24.0 \%)$ & & & & & (ref) \\
\hline Nurse & $70(28.5 \%)$ & $68(38.9)$ & & & 1.014 & $0.569-1.809$ & 0.962 \\
\hline Pharm & $26(10.6 \%)$ & $14(8 \%)$ & 16.373 & 0.003 & 0.549 & $0.238-1.267$ & 0.160 \\
\hline Secre & $43(17.5 \%)$ & $18(10.3 \%)$ & & & 0.430 & $0.205-0.903$ & 0.026 \\
\hline Other & $25(10.2 \%)$ & $33(18.9 \%)$ & & & 1.398 & $0.687-2.847$ & 0.355 \\
\hline Anxiety (\%) & & & & & & & 0.042 \\
\hline Normal & $78(31.7 \%)$ & $13(7.4 \%)$ & & & & & (ref) \\
\hline B.abnormal & $52(21.1 \%)$ & $35(20.0 \%)$ & 39.395 & $<0.001$ & 2.364 & $1.039-5.383$ & 0.040 \\
\hline Abnormal & $116(47.2 \%)$ & $127(72.6 \%)$ & & & 2.801 & $1.254-6.257$ & 0.012 \\
\hline Depression (\%) & & & & & & & 0.002 \\
\hline Normal & $81(32.9 \%)$ & $13(7.4 \%)$ & & & & & (ref) \\
\hline B.abnormal & $65(26.4 \%)$ & $47(26.9 \%)$ & 42.362 & $<0.001$ & 3.002 & $1.414-6.372$ & 0.004 \\
\hline Abnormal & $100(40.7 \%)$ & $115(65.7 \%)$ & & & 3.955 & $1.845-8.475$ & $<0.001$ \\
\hline
\end{tabular}

Pharm: Pharmacist ,Secre: Secretaries, B.abnormal: Borderline abnormal

\section{DISCUSSION}

This is the first study that assesses the relationship between bruxism and mental health in the healthcare workers after the coronavirus pandemic. The purpose of this study was to demonstrate that the pandemic process can cause not only mental but also physical problems in health workers.

It is observed that healthcare workers, who take an active role in the pandemic, are affected mentally because of their increased stress levels. ${ }^{11,14}$ Among the causes of fear, anxiety and stress in the workers are the possibility of themselves or their families being infected with the virus, limited access to official psychological support, limited infor- mation about the pandemic, lack of information to use protective equipment and less medical knowledge. ${ }^{13}$ In the current study, it was observed that the majority of the participants had depression and anxiety. These results are similar to the results of other studies on healthcare workers during the pandemic period. ${ }^{11,13,14}$

Przystańska et al. reported that psychosocial factors, especially perceived stress and anxiety, are as important as somatic factors for bruxism, etiologically. ${ }^{22}$ In another study which investigated the relationship between stress and bruxism, it was revealed that there is a direct relationship between stress scores and bruxism. ${ }^{23}$ Marin et al. evaluated the relationship between occupational stress and bruxism 
in the military aviators of an Air Force. According to the study results, the stress levels were higher in sub-officers with less professional responsibility than officers, and bruxism was directly proportional to stress. ${ }^{24}$

In the present study, when the association of bruxism with depression and anxiety was evaluated, it was observed that bruxism with anxiety and depression were seen together in the participants. These results confirm the view that anxiety and depression are important causes of bruxism. However, in the subgroup evaluation of the healthcare workers, it was found that anxiety and depression were mostly present in auxiliary healthcare personnel and infrequently in physicians. Less anxiety and depression in physicians who have more exposure to the virus can be explained by the fact that the physicians are more advantageous in professionally accessing medical information.

Emodi Perelman et al. reported that the occupation was a contributing factor for bruxism. According to this study, female high-tech workers and dentists were at greater risk for developing bruxism, and the authors linked these findings to their abnormal posture while working. ${ }^{25}$ There are no clinical studies evaluating bruxism in healthcare professionals. In the current study, we evaluated 412 healthcare workers who have been working during the pandemic. According to results, the group with the highest level of bruxism was auxiliary healthcare personnel (56.9\%), and the group with the lowest level was secretaries $(29.5 \%)$. Considering that anxiety and depression are most common among the auxiliary healthcare personnel, one can conclude that bruxism occurs secondary to anxiety and depression. In addition, the lower awareness of bruxism of the secretaries can be explained by the lack of medical education.

According to the average age of participants, the highest age was 54. Within the scope of the precautions taken in Turkey, workers aged 65 and over and those with a comorbid disease did not play an active role in the fight against the disease. The low age average in the current study can be explained by this.

In a study conducted in Peru and evaluating the relationship between work stress and bruxism in air force person- nel, it was found that the level of bruxism was at most between 31-41 years of age (15.7\%), similar to the current study. However, no significant relationship was found between age and bruxism. ${ }^{24}$ In addition, in a clinical study in which 147 computer professionals in India were evaluated for the relationship between work stress and bruxism, no significant relationship was found between age and bruxism. ${ }^{26}$ The similarity of the study results confirms that the age at which the prevalence of bruxism is high cannot be determined and it can be observed at any age from childhood to the elderly.

Studies have shown that daytime bruxism is more common among women. ${ }^{22,27}$ However, Nakata et al. found that sleep bruxism was poorly associated with the male gender. ${ }^{28}$ In this study, the prevalence of bruxism in women was higher than men, which can be explained by the fact that the majority of the nurses and medical secretaries who accepted to participate in our survey were female.

The current study has some limitations. First of all, this is a self-report survey study, which is less effective than faceto-face interviews. Secondly, it is a cross-sectional study and only shows us the mental health of the healthcare workers and its effect on bruxism in the first month of the pandemic. The lack of a control group is also one of the drawbacks of the study.

In summary, these results show that working in pandemic clinics and services affects health workers' physical health as well as mental health. In the light of these findings, when the pandemic ends, health staff, who found themselves on the front lines of the fight with the disease, will need treatment for their physical problems like bruxism. Since it plays an important role in temporomandibular disorders, bruxism should be examined by physicians.

\section{Conflict of İnterest}

The authors declare no conflict of interest.

\section{Authors' Contributions}

Concept/Design: BÇK, TŞ. Data Collection and/or Processing: BÇK, CMC, MDK, TŞ. Data analysis and interpretation: MDK, TŞ. Literature Search: BÇK, CMC. 
Drafting manuscript: BÇK, CMC, MDK, TŞ. Critical revision of manuscript: BÇK, TŞ. Supervision: BÇK, CMC, MDK.

\section{REFERENCES}

1. World Health Organization (WHO) https://www.who.int/ emergencies/diseases/novel-coronavirus-2019/events-asthey-happen. Access date: 15 June, 2020.

2. Li Q, Guan $\mathrm{X}, \mathrm{Wu} \mathrm{P}$ et al. Early transmission dynamics in Wuhan, China, of novel coronavirus-infected pneumonia. N Engl J Med 2020;382(13):1199-1207.

3. COVID-19: too little, too late? Lancet 2020;395(10226):755.

4. Day M. Covid-19: surge in cases in Italy and South Korea makes pandemic look more likely. BMJ 2020;368:751-751.

5. World Health Organization (WHO), WHO Coronavirus (COVID-19) Dashboard. https://covid19.who.int/ Access date: 05 June, 2020.

6. World Health Organization (WHO), WHO Coronavirus (COVID-19) Country Turkey. https://covid19.who.int/ region/euro/country/tr. Access date: 15 June, 2020.

7. Guan WJ, Ni ZY, Hu Y. Clinical characteristics of coronavirus disease 2019 in China. N Engl J Med. 2020;382(18):17081720.

8. Zhou P, Yang XL, Wang XG et al. A pneumonia outbreak associated with a new coronavirus of probable bat origin. Nature 2020;579(7798):270-273.

9. Wang M, Cao R, Zhang L et al. Remdesivir and chloroquine effectively inhibit the recently emerged novel coronavirus (2019-nCoV] in vitro. Cell Res 2020;30(3):269-271.

10. TC Saglik Bakanliği, COVID-19 Rehberi. https://covid19bilgi.saglik.gov.tr/depo/rehberler/COVID-19_Rehberi.pdf Access date: $1 \overline{5}$ June, 2020.

11. Kang L, Ma S, Chen M, Yang J, Wang Y, Li R, et al. Impact on mental health and perceptions of psychological care among medical and nursing staff in Wuhan during the 2019 novel coronavirus disease outbreak: A cross-sectional study. Brain Behav Immun. 2020;87:11-17.

12. Fava GA, McEwen BS, Guidi J, Gostoli S, Offidani E, Sonino N. Clinical characterization of allostatic overload. Psychoneuroendocrinology. 2019;108:94-101.

13. Tan BYQ, Chew NWS, Lee GKH et al. Psychological Impact of the COVID-19 Pandemic on Health Care Workers in Singapore. Ann Intern Med. 2020;173(4):317-320.
14. Zhang WR, Wang K, Yin L et al. Mental Health and Psychosocial Problems of Medical Health Workers during the COVID-19 Epidemic in China. Psychother Psychosom. 2020;89(4):242-250.

15. Lobbezoo F, Ahlberg J, Raphael KG, et al. International consensus on the assessment of bruxism: Report of a work in progress. J Oral Rehabil. 2018;45(11):837-844.

16. Goldstein RE, Auclair Clark W. The clinical management of awake bruxism. J Am Dent Assoc. 2017;148(6):387-391.

17. Guo H, Wang T, Niu X, Wang H, Yang W, Qiu J, et al. The risk factors related to bruxism in children: A systematic review and meta-analysis. Arch Oral Biol. 2018;86:18-34.

18. Sener S, Karabekiroğlu S, Ünlü N. Assessment of bruxism awareness and related various factors in young adults. Cumhuriyet Dent J. 2014;17(4):361-371.

19. Zigmond AS, Snaith RP. The hospital anxiety and depression scale. Acta Psychiatr Scand. 1983;67(6):361-370.

20. Aydemir O. Reliability and Validity of the Turkish version of Hospital Anxiety and Depression Scale. Turk Psikiyatri Derg. 1997;8(4):280-287.

21. Arya R. Antonisamy B, Kumar S. Sample Size Estimation in Prevalence Studies. Indian J Pediatr. 2012;79(11):14821488.

22. Przystańska A, Jasielska A, Ziarko M et al. Psychosocial Predictors of Bruxism. Biomed Res Int. 2019;2019:1-9.

23. Cavallo P, Carpinelli L, Savarese G. Perceived stress and bruxism in university students. BMC Res Notes 2016;9(1):16.

24. Marín M, Rodríguez Y, Gamboa E, et al. Level of work stress and factors associated with bruxism in the military crew of the Peruvian Air Force. Med J Armed Forces India. 2019;75(3):297-302.

25. Emodi Perelman A, Eli I, Rubin PF, et al. Occupation as a potential contributing factor for temporomandibular disorders, bruxism, and cervical muscle pain: a controlled comparative study. Eur J Oral Sci. 2015;123(5):356-361.

26. Rao SK, Bhat M, David J. Work, stress and diurnal bruxism: a pilot study among information technology professionals in the city of Bangalore, India. Int J Dentistry. 2011;2011(1):15 .

27. Shetty S, Pitti V, Satish Babu CL, et al. Bruxism: A Literature Review. J Indian Prosthodont Soc 2010;10(3):141-148.

28. Nakata A, Takahashi M, Ikeda T, et al. Perceived psychosocial job stress and sleep bruxism among male and female workers. Community Dent Oral Epidemiol. 2008;36(3):201-209. 